\title{
Mechanism of Deoxyadenosine and 2-Chlorodeoxyadenosine Toxicity to Nondividing Human Lymphocytes
}

Shiro Seto, Carlos J. Carrera, Masaru Kubota, D. Bruce Wasson, and Dennis A. Carson

Department of Basic and Clinical Research, Scripps Clinic and Research Foundation,

10666 North Torrey Pines Road, La Jolla, California 92037

\begin{abstract}
Deoxyadenosine has been implicated as the toxic metabolite causing profound lymphopenia in immunodeficient children with a genetic deficiency of adenosine deaminase (ADA), and in adults treated with the potent ADA inhibitor deoxycoformycin. However, the biochemical basis for deoxyadenosine toxicity toward lymphocytes remains controversial. The present experiments have examined in detail the sequential metabolic changes induced in nondividing human peripheral blood lymphocytes by incubation with deoxyadenosine plus deoxycoformycin, or with 2-chlorodeoxyadenosine (CdA), an ADA resistant deoxyadenosine congener with anti-leukemic and immunosuppressive properties. The lymphotoxic effect of deoxyadenosine and $\mathrm{CdA}$ required their phosphorylation, and was inhibited by deoxycytidine. As early as $4 \mathrm{~h}$ after exposure to the deoxynucleosides, strand breaks in lymphocyte DNA began to accumulate, and RNA synthesis decreased. These changes were followed by a significant fall in intracellular NAD levels at 8 $h$, a drop in ATP pools at $24 \mathrm{~h}$, and cell death by $48 \mathrm{~h}$. Incubation of the lymphocytes with $5 \mathrm{mM}$ nicotinamide, a NAD precursor and an inhibitor of poly(ADP-ribose) synthetase, prevented NAD depletion. The nicotinamide treatment also rendered the lymphocytes highly resistant to deoxyadenosine and CdA toxicity, without altering dATP formation or the accumulation of DNA strand breaks. The poly(ADPribose) synthetase inhibitor 3-aminobenzamide exerted a similar although less potent effect. These results suggest that NAD depletion, probably triggered by poly(ADP-ribose) formation, is the principle cause of death in normal resting human lymphocytes exposed to deoxyadenosine plus deoxycoformycin, or to CdA.
\end{abstract}

\section{Introduction}

A genetic deficiency of adenosine deaminase (ADA, ${ }^{1}$ adenosine aminohydrolase, EC 3.5.4.4) causes severe combined immunodeficiency disease in human beings (1-3). The selective

This is publication number BCR3544 from the Research Institute of Scripps Clinic.

Received for publication 25 June 1984 and in revised form 21 September 1984.

1. Abbreviations used in this paper: ADA, adenosine deaminase; 3ABA, 3-aminobenzamide; CdA, 2-chlorodeoxyadenosine; dATP, deoxyadenosine-5'-triphosphate; HPLC, high performance liquid chromatography; MTT, methyl thiazolyl tetrazolium.

J. Clin. Invest.

(C) The American Society for Clinical Investigation, Inc. 0021-9738/85/02/0377/07 \$1.00

Volume 75, February 1985, 377-383 lymphopenia observed in ADA-deficient patients has been attributed to the toxic effects of deoxyadenosine (4-7). When compared with other cell types, human $\mathrm{T}$ lymphoblasts exposed to deoxyadenosine in the presence of a strong ADA inhibitor, such as deoxycoformycin, preferentially accumulate deoxyadenosine-5'-triphosphate (dATP) (8-10). The dATP is an established inhibitor of mammalian ribonucleotide reductase, and hence of DNA synthesis $(11,12)$. However, micromolar concentrations of deoxyadenosine are also toxic to ADAinhibited human peripheral blood lymphocytes that are arrested in prolonged $\mathrm{G}_{0}$ phase (13-15). The ADA-resistant deoxyadenosine congener 2-chlorodeoxyadenosine (CdA) is similarly cytotoxic to resting human $\mathrm{T}$ cells, and has immunosuppressive and anti-leukemic properties $(16,17)$.

The metabolic effects of deoxyadenosine in nondividing human lymphocytes have been investigated in several laboratories. Deoxyadenosine has been reported to block RNA synthesis (18), to decrease ATP levels $(15,19)$, and to foster an accumulation of strand breaks in DNA (20). The actual importance of these events in causing cell death is entirely unknown.

Recent studies indicate that the repair of DNA strand breaks in eukaryotic cells is closely linked to the synthesis of poly(ADP-ribose) (21-23). This polymer is produced from NAD in a reaction catalyzed by the chromatin-associated onzyme poly(ADP-ribose) synthetase (24). Treatment of cells with agents which damage DNA has been shown to stimulate the synthesis of poly(ADP-ribose), resulting in rapid consumption of cellular NAD (25-27).

In the present experiments, we have monitored the sequence of metabolic changes that follow exposure of normal human peripheral blood lymphocytes to deoxyadenosine plus deoxycoformycin, or to CdA. An analysis of the data indicates that both deoxynucleosides kill resting lymphocytes mainly by lowering NAD pools. Supplementation of the medium with nontoxic concentrations of nicotinamide prevented NAD depletion and thereby protected the cells from deoxyadenosine and $\mathrm{CdA}$ toxicity.

\section{Methods}

Lymphocyte isolation and incubation. Peripheral blood mononuclear cells were isolated from the heparinized blood of normal volunteers by Ficoll-Hypaque sedimentation (28). Care was taken to shield the cells from fluorescent light. The mononuclear cells were washed three times with RPMI 1640 medium (Microbiological Assoc., Bethesda, $\mathrm{MD}$ ), and then were dispersed at a final density of $2 \times 10^{6} / \mathrm{ml}$ in the same medium supplemented with $100 \mathrm{U} / \mathrm{ml}$ penicillin, $100 \mu \mathrm{g} / \mathrm{ml}$ streptomycin, $2 \mathrm{mM}$ L-glutamine, and $20 \%$ autologous plasma (complete medium). Deoxyadenosine, $\mathrm{CdA}$, nicotinamide, and other compounds were added to the medium at concentrations indicated in Results. Before the addition of deoxyadenosine, the cells were preincubated with 1 or $5 \mu \mathrm{M}$ deoxycoformycin at $37^{\circ} \mathrm{C}$ for $30 \mathrm{~min}$. Under these 
conditions, deoxyadenosine levels in the medium were preserved for at least $72 \mathrm{~h}$.

For toxicity and metabolic studies, 5-ml suspensions of mononuclear cells were maintained in tissue culture flasks at $37^{\circ} \mathrm{C}$ in an atmosphere of $5 \% \mathrm{CO}_{2}$ in air. At intervals after the initiation of culture, the nonadherent lymphocytes were removed and processed. Cell viability was determined microscopically after the addition of erythrocin B.

Measurement of DNA strand breaks. DNA strand breaks in the various lymphocyte suspensions were measured by the fluorometric method of Birnboim and Jevcak (29). The assay is based on the observation that the rate of DNA strand unwinding in alkaline solution is inversely related to the length of intact double-stranded DNA segments $(30,31)$. In previous experiments, the strand unwinding rate correlated well with the number of breaks, or alkali-sensitive sites induced in DNA by gamma irradiation $(29,32)$. The fluorescence of ethidium bromide increases when the dye binds to double-stranded DNA (33). Therefore, a quantitative estimate of DNA strand breaks in treated cells can be made by monitoring the fluorescence of ethidium bromide added to DNA samples in alkaline solutions.

Each unwinding assay contained three sets of data points. Total fluorescence derived from cultures in which DNA unwinding was prevented. Background fluorescence came from cell suspensions that had been sonicated to permit complete DNA unwinding. The test samples provided the third set of data points. The percent residual double-stranded DNA after alkali treatment was calculated by the equation (29): Percent double-stranded DNA = (sample fluorescence - background fluorescence)/(total fluorescence - background fluorescence) $\times 100$.

After incubation with various agents, $10^{7}$ lymphocytes were resuspended in $2 \mathrm{ml}$ of a $10-\mathrm{mM}$ sodium phosphate buffer (pH 7.2) containing $0.25 \mathrm{M}$ inositol and $1 \mathrm{mM} \mathrm{MgCl}$. Aliquots of $0.2 \mathrm{ml}$ were distributed among nine assay tubes for triplicate measurements of total, background, and test condition DNA fluorescence. Cells were lysed by adding $0.2 \mathrm{ml}$ to each tube of a solution containing $9 \mathrm{M}$ urea, $10 \mathrm{mM} \mathrm{NaOH}, 2.5 \mathrm{mM}$ diaminocyclohexane-tetraacetate, and $0.1 \%$ sodium dodecyl sulfate. Lysis was complete after $10 \mathrm{~min}$ at $0^{\circ} \mathrm{C}$. At this time, $0.4 \mathrm{ml}$ of $1 \mathrm{M}$ glucose and $14 \mathrm{mM}$ 2-mercaptoethanol were added to total fluorescence tubes to prevent DNA unwinding. All tubes then received $0.2 \mathrm{ml}$ of $0.2 \mathrm{~N} \mathrm{NaOH}$, which raised the $\mathrm{pH}$ of the test and background samples to $\mathrm{pH} 12.8$ and that of the total fluorescence tubes to pH 11.2. Background aliquots were then briefly sonicated. Individual samples were incubated at $0^{\circ} \mathrm{C}$ for $30 \mathrm{~min}$ and then at $18^{\circ} \mathrm{C}$ for intervals from 0 to $90 \mathrm{~min}$. DNA unwinding was stopped by adding $0.4 \mathrm{ml}$ of $1 \mathrm{M}$ glucose and $14 \mathrm{mM} 2$-mercaptoethanol to test and background tubes. Ethidium bromide, $6.7 \mu \mathrm{g} / \mathrm{ml}$, in 13.3 $\mathrm{mM} \mathrm{NaOH}$ was added to each sample. Finally, the relative fluorescence intensity was measured in a filter fluorometer (excitation $520 \mathrm{~nm}$, analyzer $565-600 \mathrm{~nm}$ ).

As determined by this method, double-stranded DNA from untreated lymphocytes and from irradiated cells decreased linearly during 60 min incubation in alkaline solution (Fig. 1). In Results, the data for double-stranded DNA from treated cells are expressed as the percentage of double-stranded DNA from untreated control cells in a 60-min unwinding assay.

RNA synthesis. Lymphocyte RNA synthesis was estimated by measuring the incorporation of $\left[5-{ }^{3} \mathrm{H}\right]$ uridine, $(10 \mu \mathrm{Ci} / \mathrm{ml}, 17 \mathrm{Ci} / \mathrm{mmol}$ sp act, ICN, Irvine, CA) into acid precipitable material during the final $4 \mathrm{~h}$ of incubation (18). The cells were collected on glass fiber filters and were washed sequentially with isotonic phosphate-buffered saline, pH 7.4 (PBS), 10\% trichloroacetic acid, and finally with methanol. Radioactivity on the filters was then measured in a liquid scintillation counter.

Extraction of intracellular nucleotides. To extract NAD and ATP, $3 \times 10^{6}$ lymphocytes were washed with cold PBS and incubated in 0.5 $M$ perchloric acid for $15 \mathrm{~min}$ at $0^{\circ} \mathrm{C}$ (34). After centrifugation, the supernatants were brought to neutral $\mathrm{pH}$ with $1 \mathrm{M} \mathrm{KOH}$ and then frozen at $-20^{\circ} \mathrm{C}$ for $1-4 \mathrm{~d}$. To extract dATP, $1.5 \times 10^{7}$ lymphocytes were incubated in $60 \%$ methanol overnight at $-20^{\circ} \mathrm{C}$ (35). After

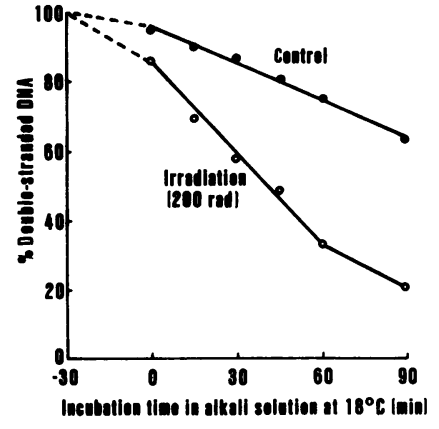

Figure 1. Kinetics of DNA unwinding in lymphocytes. Normal human peripheral blood lymphocytes were exposed to $200 \mathrm{rad}$ gamma irradiation at $4^{\circ} \mathrm{C}$ and immediately assayed for DNA strand breaks. After addition of alkali, cell lysates were maintained at $0^{\circ} \mathrm{C}$ for 30 min (dashed lines) before incubation at $18^{\circ} \mathrm{C}$. The percent doublestranded DNA was determined as described in Methods. (๑) Unirradiated cells; $(0)$ irradiated cells.

removal of precipitated material, the supernatants were diluted with water, frozen, and then lyophilized. The nucleotides were dissolved in water just before analysis by high performance liquid chromatography (HPLC).

Measurements of intracellular nucleotides. ATP and dATP were measured by HPLC as described previously (36). NAD pools were measured by an enzymatic cycling assay which was linear in the range from 6.25 to 200 pmol $\operatorname{NAD}(34,37)$. Each reaction tube contained $0.2 \mathrm{ml}$ of either cell extract or NAD standard, $0.1 \mathrm{ml}$ alcohol dehydrogenase (160 U/ml, Sigma Chemical Co., St. Louis, MO), and $1 \mathrm{ml}$ of a reaction mixture consisting of $600 \mathrm{mM}$ ethanol, $0.5 \mathrm{mM}$ methyl thiazolyl tetrazolium (MTT), $2.0 \mathrm{mM}$ phenazine ethosulfate, $5.0 \mathrm{mM}$ ethlenediaminetetraacetic acid, $1 \mathrm{mg}$ bovine serum albumin, and $120 \mathrm{mM} \mathrm{N-bis(2-hydroxyethyl)glycine,} \mathrm{pH} 7.8$. The cycling assay was initiated at $37^{\circ} \mathrm{C}$ in the dark and was terminated after 20 min by adding $0.5 \mathrm{ml}$ of $12 \mathrm{mM}$ iodoacetate. The optical density of reduced MTT was measured at $570 \mathrm{~nm}$.

Reagents. CdA was synthesized enzymatically from 2-chloroadenine as previously described (36). Deoxycoformycin was donated by $\mathbf{H}$. W. Dion (Warner-Lambert/Parke-Davis, Detroit, MI). Deoxyadenosine, nicotinamide, and 3-aminobenzamide (3-ABA) were purchased from Sigma Chemical Co., and ethidium bromide was obtained from Aldrich Chemical Co., Milwaukee, WI. Other chemicals were of the highest quality commercially available.

\section{Results}

Deoxyadenosine and $\mathrm{CdA}$ induced changes in lymphocyte viability, DNA strand breaks, and RNA synthesis. Both the combination of deoxyadenosine plus deoxycoformycin and CdA alone killed normal resting peripheral blood lymphocytes maintained in autologous plasma (Fig. 2). The lethal effects of

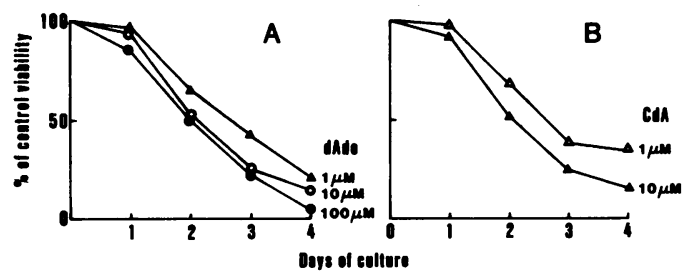

Figure 2. Toxicity of deoxyadenosine plus deoxycoformycin $(A)$ and CdA $(B)$ toward resting peripheral blood lymphocytes. The cells were incubated for $1-4 \mathrm{~d}$ in complete medium containing $1 \mu \mathrm{M}$ deoxycoformycin plus increasing concentrations of deoxyadenosine (dAdo), or containing CdA alone. Viability was determined each day by dye exclusion and was compared with control cultures without exogenous deoxynucleosides. Control cultures remained $83 \%$ viable at 4 d. Each point is the mean of two experiments. 
the two purine deoxynucleosides were dose dependent and developed slowly. Dead cells were first evident after $2 \mathrm{~d}$ and increased progressively thereafter.

The nondividing lymphocytes began to accumulate DNA strand breaks $4 \mathrm{~h}$ after incubation with deoxyadenosine plus deoxycoformycin, and $2 \mathrm{~h}$ after incubation with CdA (Fig. 3). In lymphocyte cultures supplemented with $10 \mu \mathrm{M}$ deoxyadenosine, or $1 \mu \mathrm{M} \mathrm{CdA}$, the alkali resistant double-stranded DNA had decreased to $<50 \%$ of control values by $24 \mathrm{~h}$. Deoxycoformycin alone or $100 \mu \mathrm{M}$ deoxyadenosine without deoxycoformycin produced results similar to control up to $24 \mathrm{~h}$ incubation (results not shown).

$\mathrm{CdA}$, as well as deoxyadenosine plus deoxycoformycin, blocked RNA synthesis in normal resting human lymphocytes (Table I). The decrease in $\left[5-{ }^{3} \mathrm{H}\right]$ uridine incorporation was measurable $4 \mathrm{~h}$ after the addition of the deoxynucleosides, and continued in parallel with the accumulation of DNA strand breaks (Fig. 3).

Changes in NAD and ATP levels. DNA damage in mammalian cells stimulates the synthesis of poly(ADP-ribose) from $\operatorname{NAD}(21,25,26)$. Lymphocyte NAD levels fell significantly 8 $\mathrm{h}$ after exposure to deoxyadenosine plus deoxycoformycin, or to CdA (Fig. 4). By 24 h, NAD pools were severely depleted. In contrast, lymphocyte ATP pools had not markedly changed after $8 \mathrm{~h}$ incubation with deoxyadenosine or CdA (Fig. 5). In agreement with earlier results, ATP levels decreased significantly after $24 \mathrm{~h}$ exposure to the two deoxynucleosides $(15,19)$.

Table II summarizes the time course of the effects of deoxyadenosine on ADA inhibited resting human peripheral blood lymphocytes. Notably, the sequence of significant changes was: DNA strand breakage and RNA synthesis inhibition at 4 $\mathrm{h}$; a drop in NAD levels at $8 \mathrm{~h}$; and a fall in ATP concentrations at $24 \mathrm{~h}$. As shown in Fig. 2, substantial cell death occurred after $48 \mathrm{~h}$ incubation with the deoxynucleosides.

Effects of nicotinamide and 3-ABA. Lymphocyte NAD levels reflect a balance between synthesis and consumption. Nicotinamide is both a potential NAD precursor (38) and an inhibitor of poly(ADP-ribose) synthesis $(39,40)$. By comparison, 3-ABA is a potent inhibitor of poly(ADP-ribose) synthetase (41), but has not been reported to enhance NAD synthesis. Therefore, we examined the ability of the two agents to modify the toxic and metabolic effects of deoxyadenosine and CdA.

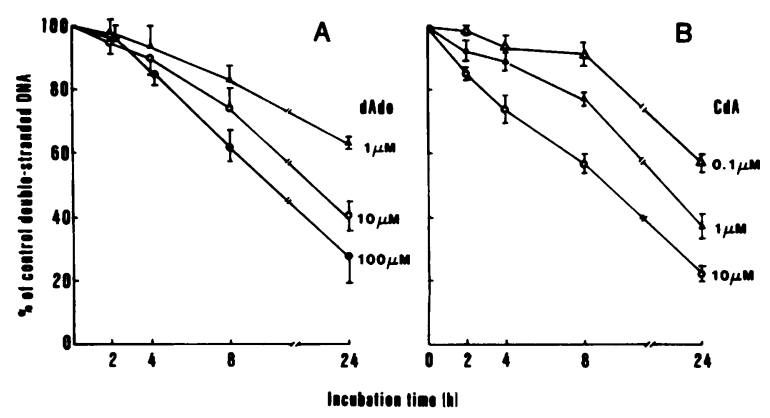

Figure 3. DNA strand breaks in peripheral blood lymphocytes incubated with deoxyadenosine (dAdo) plus deoxycoformycin $(A)$, or with CdA $(B)$. DNA strand breaks were measured as described in Fig. 1 after $60 \mathrm{~min}$ incubation in alkali. Data are shown as the percent of control cultures without deoxynucleosides. Results represent the mean \pm SEM of four experiments with deoxyadenosine and two with CdA.
Table 1. RNA Synthesis in Resting

Human Peripheral Blood Lymphocytes

\begin{tabular}{llll}
\hline & \multicolumn{3}{l}{ Incubation time } \\
\cline { 2 - 4 } Treatment & $4 \mathrm{~h}$ & $8 \mathrm{~h}$ & $24 \mathrm{~h}$ \\
\hline dAdo $(100 \mu \mathrm{M})$ & $94 \pm 5$ & $89 \pm 4$ & $90 \pm 6$ \\
dCF $(1 \mu \mathrm{M})$ & $97 \pm 6$ & $93 \pm 8$ & $99 \pm 3$ \\
dAdo $(1 \mu \mathrm{M}+\mathrm{dCF} 1 \mu \mathrm{M})$ & $85 \pm 3$ & $84 \pm 5$ & $50 \pm 19$ \\
dAdo $(10 \mu \mathrm{M}+\mathrm{dCF} 1 \mu \mathrm{M})$ & $77 \pm 1$ & $66 \pm 4$ & $33 \pm 3$ \\
dAdo $(100 \mu \mathrm{M}+\mathrm{dCF} 1 \mu \mathrm{M})$ & $65 \pm 11$ & $64 \pm 3$ & $31 \pm 1$ \\
CdA $(1 \mu \mathrm{M})$ & $86 \pm 13$ & $74 \pm 2$ & $41 \pm 1$ \\
CdA $(10 \mu \mathrm{M})$ & $70 \pm 5$ & $59 \pm 9$ & $32 \pm 9$ \\
\end{tabular}

Human peripheral blood lymphocyte suspensions were maintained in complete medium supplemented with deoxyadenosine (dAdo) and deoxycoformycin (dCF), alone or in combination, or with CdA. During the last $4 \mathrm{~h}$ of culture, the cultures were pulsed with $\left[5-{ }^{3} \mathrm{H}\right]-$ uridine (specific activity $17 \mathrm{Ci} / \mathrm{mmol}, 10 \mu \mathrm{Ci} / \mathrm{ml}$ ). Results are expressed as a percentage of the $\left[5-{ }^{3} \mathrm{H}\right]$ uridine incorporation by untreated control lymphocytes. Data represent the mean \pm SEM of three experiments. The control cpm were $5,855 \pm 1,240 / 10^{6}$ cells at $4 \mathrm{~h}$, $5,500 \pm 925$ at $8 \mathrm{~h}$, and $5,040 \pm 415$ at $24 \mathrm{~h}$.

$5 \mathrm{mM}$ nicotinamide, and to lesser extent $5 \mathrm{mM}$ 3-ABA, protected resting human peripheral blood lymphocytes from the lethal effects of deoxyadenosine plus deoxycoformycin or CdA (Fig. 6). For example, in deoxycoformycin-supplemented medium, $1 \mu \mathrm{M}$ deoxyadenosine killed $>50 \%$ of the cells after $3 \mathrm{~d}$ incubation. By contrast, in medium containing 1 or $5 \mathrm{mM}$ nicotinamide, the lymphocytes remained viable even in the presence of $100 \mu \mathrm{M}$ deoxyadenosine. The beneficial effects of nicotinamide were not attributable to inhibition of deoxyadenosine transport or phosphorylation. As shown in Fig. 7, $5 \mathrm{mM}$ nicotinamide did not alter dATP formation from deoxyadenosine. Moreover, nicotinamide had no effect on the accumulation of DNA strand breaks (Fig. 8).

The addition of increasing concentrations of nicotinamide to the lymphocyte cultures dose responsively expanded intracellular NAD pools. In the experiment shown in Fig. 9, exposure of the lymphocytes to $5 \mathrm{mM}$ nicotinamide for 24 hours raised NAD levels fourfold. Under the same conditions,

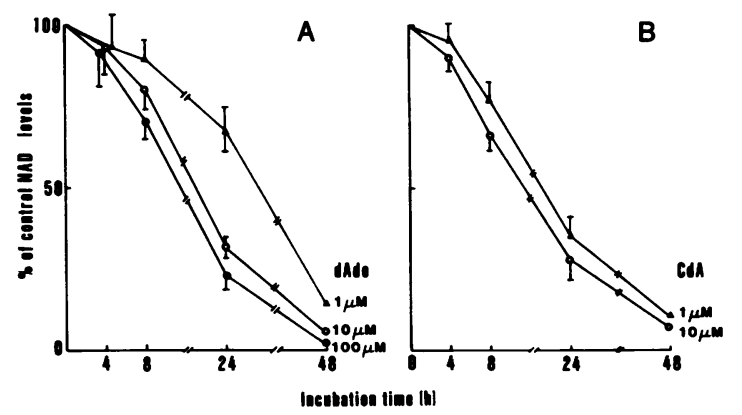

Figure 4. Effects of deoxyadenosine (dAdo) plus deoxycoformycin (A) and CdA $(B)$ on lymphocyte NAD pools. NAD was measured by the enzymatic cycling method (37). Levels of NAD are expressed as the percent of control cultures that lacked deoxyadenosine or $\mathrm{CdA}$. Control NAD levels in pmol/10 $10^{6}$ cells were $67.4 \pm 17.1$ at $4 \mathrm{~h}, 79.8 \pm 18.7$ at $8 \mathrm{~h}, 97.6 \pm 21.7$ at $24 \mathrm{~h}$, and $101.7 \pm 5.7$ at $48 \mathrm{~h}$. Results are the mean \pm SEM of four experiments with deoxyadenosine, and three with CdA. 


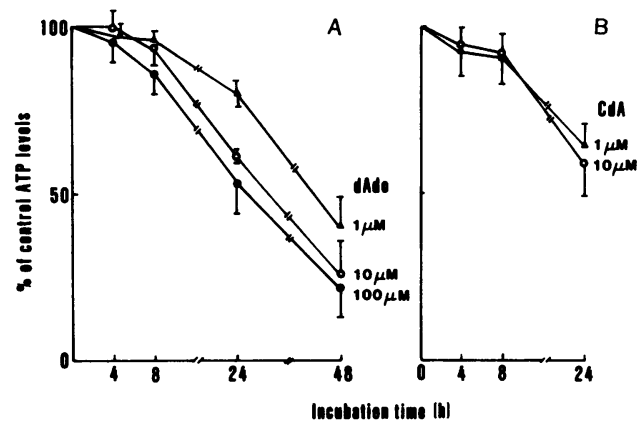

Figure 5. Effects of deoxyadenosine (dAdo) plus deoxycoformycin $(A)$ or CdA $(B)$ on lymphocyte ATP pools. ATP levels were measured by HPLC. The ATP concentrations are expressed as the percent of control cultures without deoxynucleosides. Control values in pmol/ $10^{6}$ cells were $953 \pm 109$ at $4 \mathrm{~h}, 974 \pm 114$ at $8 \mathrm{~h}, 948 \pm 167$ at $24 \mathrm{~h}$, and $925 \pm 156$ at $48 \mathrm{~h}$. Results are the mean \pm SEM of four experiments with deoxyadenosine and three with $\mathrm{CdA}$.

$1 \mathrm{mM}$ nicotinamide elevated the NAD pools threefold. The treatment also retarded the drop in NAD concentrations that followed exposure of the cells to deoxyadenosine or CdA. After $48 \mathrm{~h}$ incubation in a medium containing $5 \mathrm{mM}$ nicotinamide and either $10 \mu \mathrm{M}$ deoxyadenosine plus deoxycoformycin or 1 $\mu \mathrm{M}$ CdA, lymphocyte NAD levels were equivalent to the levels in cells that had not been exposed to the drugs. ATP pools were also higher in the nicotinamide-supplemented cultures (results not shown).

$5 \mathrm{mM}$ 3-ABA increased lymphocyte NAD pools only slightly, and was only partially effective in preventing the decline in NAD levels caused by deoxyadenosine. Approximately $1 \mu \mathrm{M}$ deoxyadenosine blocked by $50 \%$ the growth of

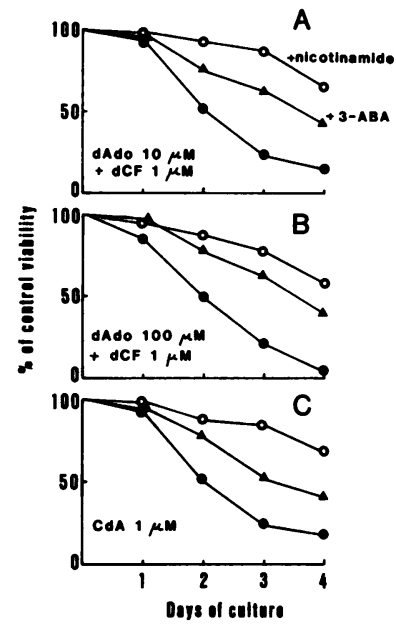

Figure 6. Prevention of deoxynucleoside toxicity by nicotinamide and 3-ABA. Peripheral blood lymphocytes incubated with deoxyadenosine (dAdo) plus deoxycoformycin (dCF) $(A$ and $B)$, or with $\mathrm{CdA}(C)$, were simultaneously exposed to $5 \mathrm{mM}$ nicotinamide (0) or to $5 \mathrm{mM} \mathrm{3-ABA} \mathrm{( \Lambda ).}$ Cell viabilities were determined by erythrocin B dye exclusion. The periments. results are the average of two ex-

the human CEM T lymphoblastoid cell line in deoxycoformycin-supplemented medium (9). Neither nicotinamide (1-5 $\mathrm{mM})$ nor 3-ABA $(5 \mathrm{mM})$ altered the growth inhibitory effects of deoxyadenosine toward the malignant $\mathrm{T}$ lymphoblasts.

Effects of deoxycytidine. Deoxycytidine is a competitive inhibitor of deoxyadenosine and $\mathrm{CdA}$ phosphorylation in human lymphocytes $(4,10,36)$. In deoxycytidine-supplemented medium, dATP formation from deoxyadenosine was impaired (Fig. 7) and DNA strand breaks did not accumulate during 24 $\mathrm{h}$ incubation. As previously reported, deoxycytidine protected resting peripheral blood lymphocytes from the lethal effects of deoxyadenosine and $\operatorname{CdA}(4,13,14)$.

Effects of thiopurines. The purine anti-metabolites 6-thioguanine and 6-mercaptopurine blocked RNA synthesis in resting lymphocytes as effectively as deoxyadenosine, but did

Table II. Metabolic Changes in Deoxyadenosine-treated Lymphocytes

\begin{tabular}{|c|c|c|c|c|c|c|c|}
\hline & \multirow{3}{*}{ dAdo } & \multicolumn{6}{|c|}{ Incubation time } \\
\hline & & \multicolumn{2}{|l|}{$4 \mathrm{~h}$} & \multicolumn{2}{|l|}{$8 \mathrm{~h}$} & \multicolumn{2}{|l|}{$24 \mathrm{~h}$} \\
\hline & & $\%$ control & $P$ & $\%$ control & $P$ & \% control & $P$ \\
\hline \multirow[t]{3}{*}{ Double-stranded DNA } & $1 \mu \mathrm{M}$ & $94 \pm 7$ & NS & $82 \pm 5$ & $<0.005$ & $63 \pm 1$ & $<0.005$ \\
\hline & $10 \mu \mathrm{M}$ & $90 \pm 5$ & $<0.05$ & $74 \pm 6$ & $<0.005$ & $41 \pm 4$ & $<0.005$ \\
\hline & $100 \mu \mathrm{M}$ & $87 \pm 3$ & $<0.05$ & $62 \pm 5$ & $<0.005$ & $28 \pm 8$ & $<0.005$ \\
\hline \multirow[t]{3}{*}{ RNA synthesis } & $1 \mu \mathrm{M}$ & $85 \pm 3$ & NS & $84 \pm 5$ & $<0.05$ & $50 \pm 19$ & $<0.01$ \\
\hline & $10 \mu \mathrm{M}$ & $77 \pm 1$ & $<0.05$ & $66 \pm 4$ & $<0.05$ & $33 \pm 3$ & $<0.005$ \\
\hline & $100 \mu \mathrm{M}$ & $65 \pm 11$ & $<0.05$ & $64 \pm 3$ & $<0.01$ & $31 \pm 1$ & $<0.005$ \\
\hline \multirow[t]{3}{*}{ NAD } & $1 \mu \mathrm{M}$ & $95 \pm 11$ & NS & $90 \pm 6$ & $<0.05$ & $68 \pm 9$ & $<0.005$ \\
\hline & $10 \mu \mathrm{M}$ & $95 \pm 10$ & NS & $81 \pm 6$ & $<0.01$ & $31 \pm 4$ & $<0.005$ \\
\hline & $100 \mu \mathrm{M}$ & $93 \pm 13$ & NS & $71 \pm 6$ & $<0.005$ & $23 \pm 4$ & $<0.005$ \\
\hline \multirow[t]{3}{*}{ ATP } & $1 \mu \mathrm{M}$ & $97 \pm 3$ & NS & $96 \pm 2$ & NS & $79 \pm 4$ & $<0.005$ \\
\hline & $10 \mu \mathrm{M}$ & $99 \pm 5$ & NS & $93 \pm 3$ & NS & $61 \pm 1$ & $<0.005$ \\
\hline & $100 \mu \mathrm{M}$ & $95 \pm 6$ & NS & $86 \pm 6$ & $<0.05$ & $53 \pm 9$ & $<0.005$ \\
\hline
\end{tabular}

Resting human lymphocytes were incubated with the indicated concentrations of deoxyadenosine in deoxycoformycin supplemented complete medium. After 4, 8, and 24 h, DNA strand breaks, RNA synthesis, NAD and ATP levels were determined. Double-stranded DNA was measured fluorometrically after 60 min alkali treatment, as described in Methods. The values for RNA synthesis, NAD levels, and ATP levels were derived from the data in Table I, Figs. 4 and 5, respectively. DNA strand breaks, NAD, and ATP pools were measured in four separate experiments, while RNA synthesis was determined three times. The deoxyadenosine-treated cultures were compared with control cultures by the twotailed paired $t$ test. Data represent the mean \pm SEM. NS, not significant. 


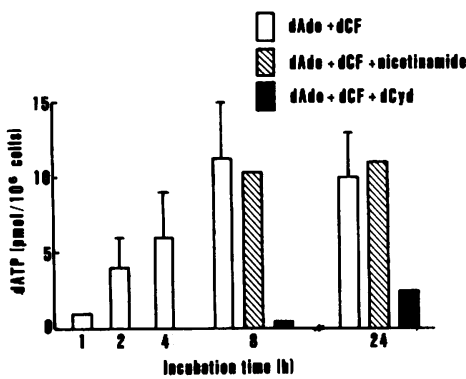

Figure 7. DeoxyATP concentrations in lymphocytes following incubation with deoxyadenosine (dAdo) plus deoxycoformycin, and the effects of nicotinamide and deoxycytidine (dCyd). Cells were incubated with 1 $\mu \mathrm{M}$ deoxycoformycin (dCF) for $30 \mathrm{~min}$ before addition of $10 \mu \mathrm{M}$ deoxyadenosine. $5 \mathrm{mM}$ nicotin-

amide or $30 \mu \mathrm{M}$ deoxycytidine was added to the lymphocyte suspensions simultaneously with deoxyadenosine. DeoxyATP was extracted in $60 \%$ methanol and measured by HPLC. Open columns represent the mean \pm SEM of three experiments.

not trigger the accumulation of DNA strand breaks (Table III). Indeed, $3 \mathrm{~d}$ exposure to the thiopurines did not significantly impair resting lymphocyte viability.

\section{Discussion}

Incubation of nondividing human peripheral blood lymphocytes with deoxyadenosine plus the strong ADA inhibitor deoxycoformycin, or with the ADA resistant deoxyadenosine analogue CdA, caused a progressive and profound drop in intracellular NAD pools. NAD depletion was measurable as early as $8 \mathrm{~h}$ after the addition of the two deoxynucleosides and closely followed the appearance of DNA strand breaks and inhibition of RNA synthesis. The lymphotoxic effects of both deoxyadenosine and CdA were blocked by co-incubation of the cells with nicotinamide, a NAD precursor (38) and inhibitor of poly(ADPribose) synthesis $(39,40)$. The latter treatment did not alter dATP formation from deoxyadenosine or the accumulation of DNA strand breaks, but preserved intracellular NAD and ATP pools. These results provide a cogent argument for a causal relation between NAD depletion and cell death.

The combination of deoxyadenosine plus deoxycoformycin partially blocks RNA synthesis in resting human lymphocytes (18). As shown here, CdA exerts a similar effect. However, the toxicity of the two compounds cannot be attributed to RNA synthesis inhibition, at least in short-term cultures. Presumably, in these long-lived, quiescent cells, incomplete inhibition of RNA synthesis is not an immediately lethal event.

The mechanism by which deoxyadenosine plus deoxycoformycin, or $\mathrm{CdA}$ alone, caused the early accumulation of DNA strand breaks in resting lymphocytes is not entirely clear. However, the present experiments clarify certain aspects of the

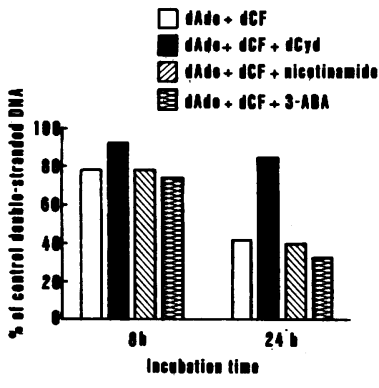

Figure 8. Effects of deoxycytidine, nicotinamide and 3-ABA on deoxyadenosine (dAdo)-induced DNA strand breaks. One $\mu \mathrm{M}$ deoxycoformycin (dCF) was added to the lymphocyte suspensions before addition of $10 \mu \mathrm{M}$ deoxyadenosine. $30 \mu \mathrm{M}$ deoxycytidine (dCyd), $5 \mathrm{mM}$ nicotinamide, or $5 \mathrm{mM} 3-\mathrm{ABA}$ was added simultaneously with deoxyadenosine. DNA strand breaks were measured as described in Methods.

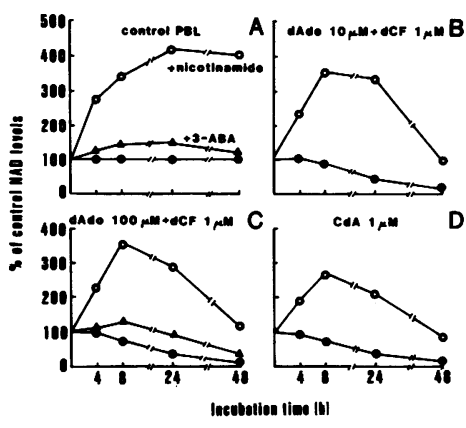

Figure 9. Effects of nicotinamide and 3-ABA on NAD levels in lymphocytes exposed to deoxyadenosine (dAdo) or CdA. NAD levels were measured by the cycling assay (37) in lymphocytes cultured: $(A)$ without deoxynucleosides; $(B)$ with $10 \mu \mathrm{M}$ deoxyadenosine plus $1 \mu \mathrm{M}$ deoxycoformycin (dCF); $(C)$ with 100 $\mu \mathrm{M}$ deoxyadenosine plus 1 $\mu \mathrm{M}$ dCF; or $(D)$ with $1 \mu \mathrm{M}$ CdA. Cells were simultaneously incubated with $5 \mathrm{mM}$ nicotinamide (0) or with $5 \mathrm{mM} 3-\mathrm{ABA}(\Delta)$. The results represent the percentage of NAD levels in untreated control cells, which were 50.7 at $4 \mathrm{~h}, 65.2$ at $8 \mathrm{~h}, 78.1$ at $24 \mathrm{~h}$, and 96.0 at $48 \mathrm{~h}$ (pmol/106 cells).

phenomenon. Deoxycytidine competitively blocked the phosphorylation of deoxyadenosine and $\mathrm{CdA}$, and in parallel diminished the accumulation of DNA strand breaks. This suggests that the respective deoxynucleotides are the actual mediators of the process. DNA strand breakage was not a nonspecific result of a block in RNA synthesis, since neither 6-thioguanine nor 6-mercaptopurine induced strand breakage at concentrations that inhibited uridine incorporation into RNA. Finally, it seems unlikely that DNA strand breaks developed solely because of a block in DNA repair mechanisms. Previous experiments have demonstrated that the pyrimidine anti-metabolite cytosine arbinoside inhibited the repair of ultraviolet-induced DNA damage in resting lymphocytes (42) but was not directly toxic to the cells (16). Conceivably, both dATP and 2-chloro-dATP interfere with a metabolic process required for the maintenance of the quaternary structure of DNA, and thereby expose the DNA to the action of endonucleases.

The accumulation of DNA strand breaks was not itself harmful to resting human lymphocytes. As noted earlier, deoxyadenosine- or CdA-treated lymphocytes incubated in nicotinamide supplemented medium remained viable for $4 \mathrm{~d}$ despite a progressive and massive increase in DNA strand breaks. However, the kinetic data, considered along with previous experiments from many laboratories, are consistent with the notion that DNA strand breakage was the event that triggered lethal NAD depletion. It is well established that both DNA-damaging chemicals and ionizing radiation stimulate poly(ADP-ribose) synthesis in normal lymphocytes, and can therefore lower NAD pools $(21,25-27)$.

Conceivably, a deoxyadenosine metabolite other than dATP may interfere with NAD synthesis or consumption. The 2'deoxy derivative of NAD, synthesized from dATP, is an established substrate for poly(ADP-ribose) synthetase (43). The NAD analogue also has been reported to inhibit DNA synthesis by isolated nuclei (44).

Pyridine nucleotides play pivotal roles in cellular metabolism. NAD is a cofactor for many different cellular dehydrogenases (45), and is a precursor of NADP (46). Depletion of NADP hampers cellular-reducing power. Moreover, lowering NAD concentrations inhibits glycolysis and ATP generation (47). This may explain the late decline in ATP levels observed in deoxyadenosine or CdA-treated lymphocyte cultures. Not 
Table III. Effects of 6-Thioguanine and 6-Mercaptopurine on Resting Human Peripheral Blood Lymphocytes

\begin{tabular}{|c|c|c|c|c|c|c|c|}
\hline \multirow[b]{2}{*}{ Treatment } & \multicolumn{3}{|c|}{$\%$ Control RNA synthesis } & \multicolumn{3}{|c|}{$\%$ Control double-stranded DNA } & \multirow{2}{*}{$\frac{\% \text { Control viability }}{72 \mathrm{~h}}$} \\
\hline & $4 \mathrm{~h}$ & $8 \mathrm{~h}$ & $24 \mathrm{~h}$ & $4 \mathrm{~h}$ & $8 \mathrm{~h}$ & $24 \mathrm{~h}$ & \\
\hline 6-Thioguanine $(10 \mu \mathrm{M})$ & $74 \pm 4$ & $55 \pm 9$ & $54 \pm 15$ & $97 \pm 1$ & $100 \pm 4$ & $95 \pm 2$ & 95 \\
\hline 6-Thioguanine $(50 \mu \mathrm{M})$ & $81 \pm 7$ & $45 \pm 7$ & $42 \pm 7$ & $97 \pm 2$ & $95 \pm 1$ & $90 \pm 1$ & 90 \\
\hline 6-Mercaptopurine $(250 \mu \mathrm{M})$ & $72 \pm 6$ & $56 \pm 11$ & $46 \pm 7$ & $100 \pm 4$ & $97 \pm 4$ & $100 \pm 1$ & 95 \\
\hline
\end{tabular}

The experiment was performed as described in Table I and Fig. 3. Cells were incubated for the indicated time period. Values are the mean \pm SEM of three determinations.

surprisingly, a severe fall in NAD pools is incompatible with the survival of resting or proliferating cells.

The exquisite sensitivity of thymocytes and mature $T$ lymphocytes to the noxious effects of deoxyadenosine is distinctive among human cell types $(4,13,15)$. In general, the tendency of the cells to accumulate dATP explains their sensitivity to deoxyadenosine. On the other hand, both thymocytes and peripheral blood lymphocytes are destroyed easily by ionizing radiation $(48,49)$, and thymocytes are also damaged by corticosteroids $(50,51)$. In common with deoxyadenosine and CdA, corticosteroids and ionizing radiation induce DNA strand breaks in lymphocytes, albeit via different mechanisms $(29,52)$. Conceivably, NAD depletion is the final common pathway that links the three immunosuppressive modalities.

The factors that regulate the levels of NAD within cells are not well understood. The pyridine nucleotide may be synthesized from tryptophan, nicotinic acid, or nicotinamide (38). The specific activity of the three biosynthetic pathways varies substantially among mammalian cell types (53). It is possible that the capacity of human lymphocytes for nicotinamide transport, or for NAD synthesis, is limited when compared with other cell types. This prediction needs to be tested experimentally.

Whether or not nicotinamide can modify the lymphotoxic effects of deoxyadenosine in ADA-deficient children remains to be seen. Certainly, nicotinamide treatment would not be expected to revert the deoxyadenosine-mediated block in thymocyte proliferation. However, dietary supplementation with relatively safe concentrations of the vitamin might conceivably improve the function of the few mature $T$ cells that survive in the immunodeficient patients. Considering the usually lethal character of the disease, this hypothesis seems worthy of further testing.

\section{Acknowledgments}

This research was supported by grants GM 23200, AM 07144, RR 00833, and CA 31497 from the National Institutes of Health.

\section{References}

1. Giblett, E. R., J. E. Anderson, F. Cohen, B. Pollara, and H. J. Meuwissen. 1972. Adenosine-deaminase deficiency in two patients with severely impaired cellular immunity. Lancet. II:1067-1069.

2. Martin, D. W., Jr., and E. W. Gelfand. 1981. Biochemistry of diseases of immunodevelopment. Annu. Rev. Biochem. 50:845-877.

3. Hirschhorn, R., and H. Ratech. 1983. Genetic deficiencies of adenosine deaminase and purine nucleoside phosphorylase and their implications for therapy of leukemias. Curr. Top. Hematol. 4:1-35.
4. Carson, D. A., J. Kaye, and J. E. Seegmiller. 1977. Lymphospecific toxicity in adenosine deaminase deficiency and purine nucleoside phosphorylase deficiency: possible role of nucleoside kinase(s). Proc. Natl. Acad. Sci. USA. 74:5677-5681.

5. Cohen, A., R. Hirschhorn, S. D. Horowitz, A. Rubinstein, S. H. Polmar, R. Hong, and D. W. Martin, Jr. 1978. Deoxyadenosine triphosphate as a potentially toxic metabolite in adenosine deaminase deficiency. Proc. Natl. Acad. Sci. USA. 75:472-476.

6. Coleman, M. S., J. Donofrio, J. J. Hutton, L. Hahn, A. Daoud, B. Lampkin, and J. Dyminski. 1978. Identification and quantitation of adenine deoxynucleotides in erythrocytes of a patient with adenosine deaminase deficiency and severe combined immunodeficiency. J. Biol. Chem. 253:1619-1626.

7. Donofrio, J., M. S. Coleman, J. J. Hutton, A. Daoud, B. Lampkin, and J. Dyminski. 1978. Overproduction of adenine deoxynucleosides and deoxynucleotides in adenosine deaminase deficiency with severe combined immunodeficiency disease. J. Clin. Invest. 62:884887.

8. Mitchell, B. S., E. Mejias, P. E. Daddona, and W. N. Kelley. 1978. Purinogenic immunodeficiency diseases: Selective toxicity of deoxyribonucleosides for T cells. Proc. Natl. Acad. Sci. USA. 75:50115014.

9. Carson, D. A., J. Kaye, and J. E. Seegmiller. 1978. Differential sensitivity of human leukemic $T$ cell lines and $B$ cell lines to growth inhibition by deoxyadenosine. J. Immunol. 121:1726-1731.

10. Hershfield, M. S., J. E. Fetter, M. C. Small, A. S. Bagnara, S. R. Williams, B. Ullman, D. W. Martin, Jr., D. B. Wasson, and D. A. Carson. 1982. Effects of mutational loss of adenosine kinase and deoxycytidine kinase on deoxyATP accumulation and deoxyadenosine toxicity in cultured CEM human T-lymphoblastoid cells. J. Biol. Chem. 257:6380-6386.

11. Thelander, L., and P. Reichard. 1979. Reduction of ribonucleotides. Annu. Rev. Biochem. 48:133-158.

12. Ullman, B., L. J. Gudas, A. Cohen, and D. W. Martin, Jr. 1978. Deoxyadenosine metabolism and cytotoxicity in cultured mouse T lymphoma cells: a model for immunodeficiency disease. Cell. 14:365-375.

13. Kefford, R. F., and R. M. Fox. 1982. Purine deoxynucleoside toxicity in non-dividing human lymphoid cells. Cancer Res. 42:324330.

14. Kefford, R. F., and R. M. Fox. 1982. Deoxycoformycin-induced response in chronic lymphocytic leukemia: deoxyadenosine toxicity in non-replicating lymphocytes. Br. J. Haematol. 50:627-636.

15. Carson, D. A., D. B. Wasson, E. Lakow, and N. Kamatani. 1982. Possible metabolic basis for the different immunodeficient states associated with genetic deficiencies of adenosine deaminase and purine nucleoside phosphorylase. Proc. Natl. Acad. Sci. USA. 79:3848-3852.

16. Carson, D. A., D. B. Wasson, R. Taetle, and A. Yu. 1983. Specific toxicity of 2-clorodeoxyadenosine toward resting and proliferating human lymphocytes. Blood. 62:737-743.

17. Carson, D. A., D. B. Wasson, and E. Beutler. 1984. Antileukemic and immunosuppressive activity of 2-chloro-2'-deoxyadenosine. Proc. Natl. Acad. Sci. USA. 81:2232-2236. 
18. Matsumoto, S. S., J. Yu, and A. L. Yu. 1983. Inhibition of RNA synthesis by deoxyadenosine plus deoxycoformycin in resting lymphocytes. J. Immunol. 131:2762-2766.

19. Siaw, M. F. E., B. S. Mitchel, C. A. Koller, M. S. Coleman, and J. J. Hutton. 1980. ATP depletion as a consequence of adenosine deaminase inhibition in man. Proc. Natl. Acad. Sci. USA. 77:61576161.

20. Brox, L., A. Ng, E. Pollock, and A. Belch. 1984. DNA strand breaks induced in human $\mathrm{T}$-lymphocytes by the combination of deoxyadenosine and deoxycoformycin. Cancer Res. 44:934-937.

21. Berger, N. A., G. W. Sikorski, S. J. Petzold, and K. K. Kurohara. 1979. Association of poly(adenosine diphosphoribose) synthesis with DNA damage and repair in normal human lymphocytes. J. Clin. Invest. 63:1164-1171.

22. Durkacz, B. W., O. Omidiji, D. A. Gray, and S. Shall. 1980. (ADP-ribose) ${ }_{n}$ participates in DNA excision repair. Nature (Lond.). 283:593-596.

23. Creissen, D., and S. Shall. 1982. Regulation of DNA ligase activity by poly(ADP-ribose). Nature (Lond.). 296:271-272.

24. Hayaishi, O., and K. Ueda. 1977. Poly(ADP-ribose) and ADPribosylation of proteins. Annu. Rev. Biochem. 46:95-116.

25. Skidmore, C. J., M. I. Davies, P. M. Goodwin, H. Halldorsson, P. Lewis, S. Shall, and A-A. Zia'ee. 1979. The involvement of poly(ADP-ribose) polymerase in the degradation of NAD caused by gamma radiation and $\mathrm{N}$-methyl-N-nitrosourea. Eur. J. Biochem. 101:135-142.

26. Rankin, P. W., M. K. Jacobson, V. R. Mitchell, and D. L. Busbee. 1980. Reduction of nicotinamide adenine dinucleotide levels by ultimate carcinogens in human lymphocytes. Cancer Res. 40:18031807.

27. Benjamin, R. C., and D. M. Gill. 1980. Poly(ADP-ribose) synthesis in vitro programmed by damaged DNA. J. Biol. Chem. 255: 10502-10508.

28. Boyum, A. 1976. Isolation of lymphocytes, granulocytes and macrophages. Scand. J. Immunol. 5(Suppl. 5):9-15.

29. Birnboim, H. C., and J. J. Jevcak. 1981. Fluorometric method for rapid detection of DNA strand breaks in human white blood cells produced by low doses of irradiation. Cancer Res. 41:1889-1892.

30. Rydberg, B. 1975. The rate of strand separation in alkali of DNA of irradiated mammalian cells. Radiat. Res. 61:274-287.

31. Kohn, K. W., L. C. Erickson, R. A. G. Ewig, and C. A. Friedman. 1976. Fractionation of DNA from mammalian cells by alkaline elution. Biochemistry. 15:4629-4637.

32. Greer, W. L., and J. G. Kaplan. 1983. DNA strand breaks in murine lymphocytes: induction by purine and pyrimidine analogues. Biochem. Biophys. Res. Commun. 115:834-840.

33. Morgan, A. R., and D. E. Pulleyblank. 1974. Native and denatured DNA, cross-linked and palindromic DNA and circular covalently-closed DNA analyzed by a sensitive fluorometric procedure. Biochem. Biophys. Res. Commun. 61:396-403.

34. Jacobson, E. L., and M. K. Jacobson. 1976. Pyridine nucleotide levels as a function of growth in normal and transformed 3T3 cells. Arch. Biochem. Biophys. 175:627-634.

35. Munch-Peterson, B., G. Tyrsted, and B. Dupont. 1973. The deoxyribonucleoside 5'-triphosphate (dATP and dTTP) pool in phy- tohemagglutinin-stimulated and non-stimulated human lymphocytes. Exp. Cell. Res. 79:249-256.

36. Carson, D. A., D. B. Wasson, J. Kaye, B. Ullman, D. W. Martin, Jr., R. K. Robins, and J. A. Montgomery. 1980. Deoxycytidine kinase-mediated toxicity of deoxyadenosine analogs toward malignant human lymphoblasts in vitro and toward murine L1210 leukemia in vivo. Proc. Natl. Acad. Sci. USA. 77:6865-6869.

37. Bernofsky, C., and M. Swan. 1973. An improved cycling assay for nicotinamide adenine dinucleotide. Anal. Biochem. 53:452-458.

38. Greenbaum, A. L., and S. Pinder. 1968. The pathway of biosynthesis of nicotinamide-adenine dinucleotide in rat mammary gland. Biochem. J. 107:55-62.

39. Berger, N. A., and G. W. Sikorski. 1980. Nicotinamide stimulated repair of DNA damage in human lymphocytes. Biochem. Biophys. Res. Commun. 95:67-72.

40. Sims, J. L., G. W. Sikorski, D. M. Catino, S. J. Berger, and N. A. Berger. 1982. Poly(adenosine-diphosphoribose) polymerase inhibitors stimulate unscheduled deoxyribonucleic acid synthesis in normal human lymphocytes. Biochemistry. 21:1813-1821.

41. Purnell, M. R., and W. J. D. Whish. 1980. Novel inhibitors of poly(ADP-ribose) synthetase. Biochem. J. 185:775-777.

42. Yew, F. F. H., and R. T. Johnson. 1979. Ultraviolet-induced DNA excision repair in human $B$ and $T$ lymphocytes. II. Effects of inhibitors and DNA precursors. Biochim. Biophys. Acta. 562:240-251.

43. Lichtenwalner, D. M., and R. J. Sudaholnik. 1979. Adenosine diphosphate ribosylation of histone and nonhistone chromosomal proteins with oxidized nicotinamide adenine dinucleotide and 2 'deoxynicotinamide adenine dinucleotide using nuclei isolated from rat liver and HeLa cells. Biochemistry. 18:3749-3755.

44. Sudaholnik, R. J., R. Baur, D. M. Lichtenwalner, T. Uematsu, J. H. Roberts, S. Sudhakar, and M. Smulson. 1979. ADP-ribosylation of isolated nuclei from HeLa cells, rat liver, fetal rat liver, and Novikoff hepatoma. J. Biol. Chem. 252:4134-4144.

45. Jeffery, J. 1980. Dehydrogenase requiring nicotinamide coenzymes. Experientia. Suppl. 36:1-272.

46. Kornberg, A. 1950. Enzymatic synthesis of triphosphopyridine nucleotide. J. Biol. Chem. 182:805-813.

47. Roitt, I. M. 1956. The inhibition of carbohydrate metabolism in ascites-tumour cells by ethyleneimines. Biochem. J. 63:300-307.

48. Prosser, J. S. 1976. Survival of human T and B lymphocytes after X-irradiation. Int. J. Radiat. Biol. 30:459-465.

49. Kwan, D. K., and A. Norman. 1977. Radiosensitivity of human lymphocytes and thymocytes. Radiat. Res. 69:143-151.

50. Claman, H. N. 1972. Corticosteroids and lymphoid cells. $N$. Engl. J. Med. 287:388-397.

51. Wylie, A. H. 1980. Glucocorticoid-induced thymocyte apoptosis is associated with endogenous endonuclease activation. Nature (Lond.). 284:555-556.

52. Cohen, J. J., and R. C. Duke. 1984. Glucocorticoid activation of calcium-dependent endonuclease in thymocyte nuclei leads to cell death. J. Immunol. 132:38-42.

53. Hillyard, D., M. C. Rechsteiner, and B. M. Olivera. 1973. Pyridine nucleotide metabolism in mammalian cells in culture. J. Cell. Physiol. 82:165-180. 